\title{
The Evaluation of the Impact of Tourism on Residents: The Case of Taormina
}

\section{Silvia Platania (PhD in Educational Science)}

Adjunct Lecturer in Work and Organizational Psychology, Department of Educational Science University of Catania; Email: splatani@unict.it

\section{Giuseppe Santisi (PhD in Political Science)}

Associate Professor of Work and Organizational Psychology, Department of Educational Science University of Catania; Email: gsantisi@unict.it

\section{Doi:10.5901/mjss.2016.v7n2s1p88}

\begin{abstract}
This study aims to explore residents' attitudes toward tourism and how these attitudes could be influenced by factors such as of one's subjective sense of well-being and personal satisfaction with life. The study's empirical geographical context is Taormina, a Sicilian community with high touristic frequency. Taormina is a popular resort town in Sicily with many interesting sights and attractions. The town's historical heritage also encloses Sicily's history: Greeks, Romans, Byzantines, Arabs, Normans, Swabians, the French, and the Spanish all came to the island, saw, conquered, and left (Oktay, 2006). Today, Taormina lives on tourism. Visitors flock from all the world to see its Greek-Roman theatre, to amble along its perfectly preserved Medieval streets (Roccuzzo, 2001). Our study involved 215 residents, the measurement scales used for the research were the Tourism Impact Attitude Scale-TIAS (Lankford, Howard, 1994), the Satisfaction with Life Scale-SWLS (Diener, Emmons, Larsen \& Griffin, 1985) and the affective and evaluative attitude of the residents towards the tourism phenomenon (Osgood, Suci \& Tannenbaum, 1957). Results show the measure of influence of residents' satisfaction with life and the impact on their attitudes regarding economic and personal tourism. The results suggest that there is average life satisfaction compensates in part for the relationship shown between TIAS and Attitude Toward Global by the residents of Taormina.
\end{abstract}

Keywords: Well-being, Satisfaction, Impact, Attitude, Tourism

\section{Introduction}

The phenomenon of tourism is a fundamental component in the economic development of those countries that are best prepared to welcome it. The set of primary infrastructures which best develop the economy in this context are transport, reception facilities, retail outlets, and these sectors considerably influence tourist travel choices (Harrill, 2004). The changes brought about upon the territory and its economic and social fabric acquire, of course, a positive value when this phenomenon is seen as a resource for the creation of professional opportunities and to improve the relevant infrastructures in the community (Brunt \& Courtney, 1999), but have negative effects when, in fact, such a transformation is considered counter-productive or even damaging for the community at large (Allen, Long, Perdue \& Kieselbach, 1988; Getz, 1986; Pizam, 1978). The close relationship between territorial development and profit potential of the tourism business in the course of the last few decades, has led specialists in the field to pay particular attention to the relationship between residents and tourists (Maeran, 2004; Platania, 2013; Platania \& Privitera, 2006). The measure of involvement in the resident population in relation to the implementation of policies for the planning and development of tourism, in fact, turns out to be the main factor influencing the quality and direction, positive or negative, of the impact of tourism on the local economy (Santisi \& Alario, 2014; Platania, 2014). The specific objective of the study presented here is to investigate whether the attitude of residents regarding the tourist phenomenon and its impact on the community can be influenced by their expressed sense of well-being and satisfaction in the citizenry's own lives (Rasoolimanesh, Jaafar, Kock \& Ramayah, 2015).

\subsection{Review of literature}

The study of this resident-tourist- relationship in recent years has been limited to a superficial economic analysis, mostly 
focused on the role of the tourist considered only as a consumer who pays to have a efficient service rendered by the host community (Wall \& Mathieson, 2006; Woosnam \& Norman, 2010). It was only during the period of the 1970's that the resident's point of view started to receive more attention, as shown by the great number of studies in literature regarding the attitude of residents towards tourists (Almeida-Santos \& Buzinde, 2007; Ishikawa \& Fukushibe, 2006; Lepp, 2007; McGehee \& Andereck, 2004; Ryan \& Cave, 2005; Zhang, Inbakaran, \& Jackson, 2006).

In particular, certain studies have focused on very different contexts: from rural communities (Wang \& Pfister, 2008) to urban areas (Harrill \& Potts, 2003), from the mountainous regions (Nepal, 2008) to the coastal areas (Andriotis \& Vaughan, 2003), then analyzing the impact that different approaches to tourism involve from locally- sustained expenditures (Sirakaya-Turk, Ekinci \& Kaya, 2008) to nationally-indebted (Gursoy, Chi \& Dyer, 2010).

Much less input from analysis has been able to offer theoretical models for the study of these constructs. The references have been largely limited to the theory of community sentiment (Jurowski, 1998; McCool \& Martin, 1994; Um \& Crompton, 1987; Vesey \& Dimanche, 2000; Williams, McDonald, Riden \& Uysal. 1995), the theory of social exchange (Getz, 1994; McGehee, Andereck \& Vogt, 2002; Perdue et Al., 1990) and the theory of the "Growth Machine" (Canan \& Hennessy, 1989; Martin, McGuire \& Lawrence, 1998).

Despite the diversity of approaches and content, research developed in this field shares the utilization of a predefined set of independent variables (Huh \& Vogt, 2008; Draper, Woosnam \& Norman, 2011) adopted to predict the perceptions of residents towards tourism, such as the traditional socio-demographic dimensions (e.g. age, gender, education, length of residence, ethnicity), socio-economic (income and economic dependence in tourism activities); those most closely linked to the geographical space-dimension (e.g. physical distance between residents and tourists); and, finally, those studies that focus on the travel habits of the resident (e.g. number of national and international trips made). These studies lead to differing, not always consistent results. (for a relatively complete analysis, refer to Harrill, 2004)

Recently, literature on this topic has increased interest in analyses that focus on the quality of life (Schalock, 1996) and subjective well-being (Filep \& Deery, 2010), which are useful in explaining the attitude of residents towards the tourist phenomenon and, in particular, these studies emphasis on creating a hypothesis envisioning a concept of tourism that positively influences the level of subjective well-being and resident quality of life (Andereck \& Nyaupane, 2011: Nawijn \& Mitas, 2011).

In the description of subjective well-being, scholars generally refer to two components, a "hedonistic level of affect", or "affective" component (Veenhoven, 2009), which refers to the concept of happiness experienced by the individual- and the "satisfaction with their life", or the "cognitive" component, referring to a process of evaluation of quality of life based on personal criteria (Santisi \& Platania, 2014; Santisi, Platania \& Hichy, 2014). These results, however, do not take into consideration how perceptions of tourism and the attitude of tourists can be closely determined by the level of well-being and satisfaction with one's life.; those factors that could, in some way, constitute prerequisites for a positive or negative attitude towards tourism, and not only regarding its consequences.. The concept of "attitude" is, in fact, defined as a prolonged predisposition towards a particular aspect of the surrounding environment. This aspect is reinforced by perceptions and beliefs about reality but at the same time are strongly influenced by the values and personality of the individual (Getz, 1994). Therefore, the attitudes of residents towards tourists do not change readily, and cannot be simply considered as deriving from the knowledge that the former have about the impact of tourism on their quality of life (Wang \& Pfister, 2008) or by some demographic and socio-economic elements, but rather have to do with beliefs that the resident himself has internalized and self-identified (Carmichael, 2006).

In this regard, existing literature on the subject contains a number of theoretical contributions that attempt to provide a description of the typical evolution in stages of residents' attitudes towards tourism. Doxey (1975), in his model gauging an index of "tourist irritation", shows the presence of four different phases that the community would succumb to with increasing impact from tourism: from euphoria to apathy, successively to irritation, finally culminating in open antagonism.

Butler (1980) proposes a similar approach in which the community itself would be involved in developing greater awareness including adopting an attitude of opposition to the consequences of tourism, including proposing diverse theoretical models to describe and categorize the attitudes assumed by the residents affected by tourism, divided into grades of higher or lower acceptance. (Butler, 1975; Dogan, 1989; Ap \& Crompton, 1993)

The present study, therefore, aims to better understand how the attitudes of residents towards tourism may be related to a more complex set of factors, both external and environmental- economic and socio-demographic factors; also internal subjective well-being experienced and deriving satisfaction from one's lives. The assumption is that these factors may affect the image of the tourist as just "another", thus transforming in extremes the "resident-tourist" label into dichotomous terms such as, "self vs other" (McNaughton, 2006),.

The context dealt with, as above, concerns the territory of the town of Taormina in Messina (ME), has about 11,000 
inhabitants, and has been an internationally- known tourist center since the early 1900's, offering a myriad of both mass and luxury tourist related "products" covering a range from beach tourism to cultural, natural, and business attractions (Oktay, 2006; Platania \& Santisi, 2014). This resort, in virtue of its natural, historical, and recreational offerings, has a significant annual impact on tourism statistics. An interesting fact is that since 2006, a 35\% increase in foreign visitor presence has been documented. Finally, it seem also interesting to note, that the market- share of tourism demand in Sicily shows that in the most recent period there has been a slight but steady increase in tourist flow, especially in relation to the area's capacity to attract more arrivals rather than just serve those already in the territory (Apostolopoulos, Leontidou e Loukissas, 2014).

\subsection{Research framework and hypotheses}

The present study aims to identify the attitude of the residents towards the tourism phenomenon in high-density tourist resorts such as Taormina, also registering if and how this attitude is influenced by the degree of satisfaction of the residents in relation to their daily lives. To register these data, a TIAS (Tourism Impact Attitude Scale) system was utilized (Lankford \& Howard, 1994) in the European version adapted by Bachleitner \& Zims (1999). This statistical instrument is now considered the most reliable two-dimensional scale of measurement correlating data not only with the attitude of residents towards tourism, but also with other variables, such as the level of contact of tourist presence, the rate of growth of the community, gender, income, and sensitivity to environmental concerns (Um \& Crompton, 1987).

With regard to the statistics determining subjective "well-being", reference was made to its related cognitive component, expressed in terms of life "satisfaction". The instrument used is the Satisfaction With Life Scale - SWLS (Diener, Emmons, Larsen \& Griffin, 1985). In particular, the instrument measures the satisfaction expressed by the individual in each relevant area of their life compared to the standard of a subjective rather than external criteria, permitting the development of an over-all "satisfaction with life" scale (Diener, 1984; Diener, Emmons, Larsen \& Griffin, 1985). Recent research has pointed out that residents' perception of the impact of tourism is influenced, indeed, by the satisfaction with life quotient, understood as a cognitive component (Nawijn \& Mitas, 2012).

These factors taken together lead to the following hypotheses to be tested in this research paper:

$\mathrm{H} 1$ : The relationship between tourist-resident is strongly influenced by variables of the environment, both social and economic.

$\mathrm{H} 2$ : The positive impact of tourism on attitude increases if there is resident awareness of economic benefit.

H3: Residents with improved economic and social position have greater "life satisfaction".

H4: The over-all attitude of residents towards tourism is positively correlated with the perception of its impact.

H5: The life satisfaction variable partially mediates the over-all attitude towards tourism and the perception of its impact.

\section{Measures}

\subsection{Sample and Data Collection Procedure}

The research project, conducted through a questionnaire, involving 215 residents in the town of Taormina (100 male and 115 female), mainly aged between 26 and 45 years (67.9\%), and have in most cases, a diploma from upper secondary school (61.9\%). In reference to employment status, $26.5 \%$ of interviewees declared they were public employees, followed by $28 \%$ freelance/entrepreneurs. A substantial percentage of participants (45.6\%) declared a net annual income of less than 30,000 Euro. Linear structural equation models were calibrated to test the hypothesized models. Tests were completed in AMOS 21.0 (Arbuckle \& Wothke, 1999). The participation to the study was completely voluntary, data were collected anonymously and the participants could refuse their participation in any moment. Research procedures have complied with the ethical guidelines and code of conduct of the APA and AIP (Italian Psychological Association).

\subsection{TIAS}

To measure the attitude of the residents towards tourist flow there was utilized the Tourism Impact Attitude Scale- TIAS (Lankford \& Howard, 1994), as adapted to the European context by Bachleitner \& Zins (1999). The scale consists of 20 items (13 items in the original TIAS, and 7 added items to measure the psychological-social impact), which provide an indication of the response to the 5-point Likert reference scale, from 1 ("strongly disagree") to 5 ("strongly agree"). 
The instrument is divided into six sub scales: "tourism development", "personal benefits" and "infrastructures" which are integrated into factors, "economy and infrastructure", "crowding", "pollution" and "discrimination", that, in turn , are related to "concern for the environment". Respectively, the alpha factor, "economy and infrastructure" and "concern for the environment" are equivalent to alpha .88 and .86. The choice of the designated model is derived from the knowledge that the structural component remains stable even during economic and social changes (Bachleitner \& Zins, 1999) (in this sense, the environmental dimension of resident perceptions is much more sensitive to changes on a large scale) (Lindberg \& Johnson, 1997).

\subsection{SWLS}

To measure the level of satisfaction with one's lives, the Satisfaction with Life Scale-SWLS (Diener, Emmons, Larsen \& Griffin, 1985) was utilized. It is an instrument that consists of 5 items to which it is necessary to indicate one's level of disagreement/agreement on a Likert 7-point scale, from 1 ("strongly disagree") to 7 ("strongly agree"). The alpha of the SWLS is equal to a.87. The Satisfaction with life Scale was developed as a measure of the judgmental component of subjective well-being (SWB). The judgmental component was also conceptualized as life satisfaction. Evidence for the reliability and predictive validity of the SWLS is presented, and its performance is compared to other related scales. In addition, the high convergence of self and peer-reported measures of subjective well-being and life satisfaction provide strong evidence that subjective well-being is a relatively global and stable phenomenon.

\subsection{The Evaluative and Affective Attitude of the Residents Towards the Tourism Phenomenon}

To measure the affective and evaluative attitude assumed towards tourism there was implemented a semantic differential (Osgood, Suci \& Tannenbaum, 1957) to 7 points. Participants were asked to express their evaluation of a concept-stimulus, "Tourism in Sicily...." Through a series of pairings of bipolar adjectives that represent the extremes of a continuum with respect to which the subject has to indicate every time how close the concept-stimulus comes to one adjective rather than the other. The instrument is composed of 17 pairs of bipolar adjectives: ten pairs to measure the evaluative attitude (e.g. "useful-useless") and 7 pairs to measure the affective attitude (e.g. "pleasant-unpleasant"). The alpha for the affective and evaluative attitude is equal to $a .83$ and a.76, respectively. Over, the two variables measure the over-all attitude of residents towards tourism.

\section{Results}

With regard to tourism impact, namely, the attitude that Taormina resident has developed towards tourism, the results that emerge from the responses given to the Tourism Impact Attitude Scale (TIAS) (Table 1) indicate that the two main factors of TIAS (Economy and Infrastructure, Environmental Concern) and the six subscales (Tourism Development, Personal Economic Benefits, Infrastructure, Crowding, Pollution, Discrimination) represent all sufficiently high values of Alpha, which give useful indications for the analysis of the model's validity. In addition, the subscale that has the highest average value is "Personal Economic Benefits" ( $M=4.25, S D=1.60)$, followed by "Infrastructure" $(M=4.15, S D=1.26)$. These results indicate, firstly, that there is both a good degree of awareness regarding personal and economic benefits tourism creates, and also that, thanks to this factor, there has been an improvement in civic-oriented infrastructures and thus better services offered to the community at large.

Table 1. Summary Statistics and Alpha's Cronbach values N=215

\begin{tabular}{lllcc}
\hline Tias's Factor & Aggregated Subscale & \multicolumn{2}{c}{ Mean Standard Deviation Alpha's Cronbach } \\
\hline \multirow{3}{*}{ Economy and Infrastrucuture } & Tourism Development & 4.10 & .90 & .64 \\
& Infrastructure & 4.60 & .79 \\
\multirow{2}{*}{ Enviromental Concern } & Crowding & 3.77 & .5 & .68 \\
& Pollution & 3.20 & .71 & .80 \\
& Discrimination & 3.99 & .52 & .85 \\
& & & & .71 \\
\hline
\end{tabular}

Another aspect to consider, however, is also the sub-scale "Discrimination" $(M=3.99, S D=.52)$. Residents show impatience with the fact that greater importance is attributed to tourism than to the needs of the local workers, who show- 
on one hand- a desire to be taken more into account, while residents seem to recognize that, thanks to tourism, there indeed exist benefits, as can be seen from the responses to the item, "Tourism promotes events and occasions for entertainment which I can also take advantage of " $(M=4.14, S D=.98)$. Also, the "t" test for independent samples showed that more women $(M=4.19, S D=.99)$ than men $(M=4.00, S D=.77, t(213)=1.47, p<.05)$ believe that tourism is important for the economic development of the community, therefore supporting Hypothesis 1. The taxpayer declaring an income of over 70,000 Euro confirms willingness to pay more taxes to support the development of tourism $F(7.763) d f=2 ; p<.001$, while those with an income ranging from 30,000 to 70,000 Euro declare that they would like tourism to become the main economic investment $F(26.308) d f=2 ; p<.001$, and that it would provide more jobs for the local population $F(5.186)$ $\mathrm{df}=2 ; \mathrm{p} .007$. Another interesting finding relates to the professions: the unemployed worker feels significantly more than others that the growth of tourism has fostered an increase in prices $F(6.142) d f=6: p<.001$. This result can be interpreted by referring to the fact that- compared to other resorts in Italy- Taormina has higher prices for consumers because a significant part of its tourist business is tied to a "target" figure, certainly not mass tourism, and this leads to a contradiction in terms of economic opportunities for those who are unemployed and live in the area, therefore supporting Hypothesis 2. Finally, whoever is part of an age group ranging from 35 to 44 years of age significantly believes that, "Tourists are precious." $F(25,048) \mathrm{df}=4$; $p<.001$.

With regard to the scale of life satisfaction (SWLS; Graph 1.), the subjective judgement emerges from the comparison between the reality of one's own life and the standard of reference data referring to one's ideals (Diener, Emmons, Larsen \& Griffin, 1985). The results (Graph 1.) indicate that the item with the highest average value is, "So far I have gotten the important things I want in life" ( $M=4.56, S D=1.40)$, while the item that has the lowest average value is, "In most ways, my life is close to my ideal." ( $M=2.83, S D=.35)$. Regarding the analysis of the differences for life satisfaction in the context of perceived socio-demographic variables, results show that those who have a post-graduate academic qualification derive greater life satisfaction (measurable in the answers given to all items) compared to those who have inferior level academic titles (significant results in all respects univariate effects $\mathrm{Fs}(31.754), \mathrm{df}=3 ; \mathrm{p}<.001$ ); while those who work as "freelance" express beliefs that - in many ways- their lives are as close to an ideal (significant results in all respects univariate effects $F s(7.508) d f=6 ; p<.001)$, and that their life conditions are excellent $[F(27.810)$ $d f=6 ; p<.001]$. Besides this, those whose ages range from 45 to 54 years show in all items greater life satisfaction than the others (significant results in all respects, univariate effects Fs (18.686) $d f=4 ; p<.001$ ), as well as those who have an income over 70,000 Euro (significant results in all respects univariate effects Fs (19.803) $d f=2 ; p<.001$ ). These results suggest that the economic and professional components substantially affect the perception of greater satisfaction with their lives, supporting Hypothesis 3.

Graph 1. Means Value SWLS scale

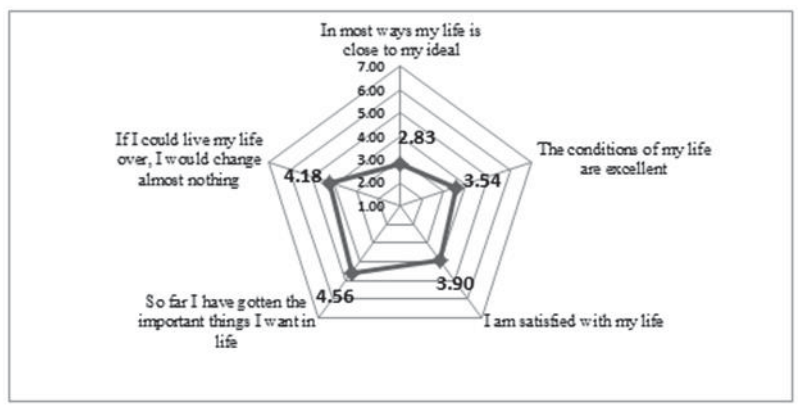

As one can see in Table 2, which shows the descriptive statistics and correlations, the relationship is significant for all three construct (the over-all attitude of residents towards tourism, life satisfaction and perceived impact of tourism from POV of residents) The stronger relationship is expressed by the TIAS ( $r=.50)$ with the overall attitude towards tourism as expressed by the resident. This indicates that there is a connection between the a priori attitude that one assumes towards tourism and the impact that the tourist phenomenon has on one's life, supporting Hypothesis 4. 
Table 2. Descriptive statistics and correlations of aggregated data Sample size $N=215^{* \star}\left({ }^{* \star} p<.001\right)$

\begin{tabular}{lccccc}
\hline Variables & M & SD & 1 & $\mathbf{2}$ & $\mathbf{3}$ \\
\hline 1. ATTITUDE TOWARDS GLOBAL TOURISM & 4.01 & 0.78 & & & \\
2. SWLS & 3.83 & 1.25 & $0.47^{\star \star}$ & & \\
3. TIAS & 3.91 & 0.62 & $0.50^{\star *}$ & $0.24^{* *}$ \\
\hline
\end{tabular}

In Table 3 and the graph below there are shown the values obtained through the process of mediation by Baron and Kenny (1986), the Hypothesis (4) provided that the perception by the resident on the effective impact of tourism was positively correlated with the "over-all attitude towards the tourist phenomenon.". The results support the hypothesis $\left(\beta=.50 ; R^{2}=.25 ; p<.001\right)$. These results are in line with Hypothesis 5 , which provides that life satisfaction acts as a mediator between the global attitude towards tourism and perceived impact of tourism as seen by residents. On the basis of the procedure used (Baron \& Kenny, 1986) to confirm the meditation, the perception of the tourism's impact must provide for the satisfaction of life and the relationship between this perception and the global attitude towards tourism, which must be drastically reduced. The results presented in the Table show that: (a) the TIAS predicts the global attitude towards tourism ( $\left.\beta=.50 ; R^{2}=.25 ; p<.001\right)$; (b) the TIAS predicts life satisfaction $\left(\beta=.24 ; R^{2}=.06 ; p<.001\right)$; (c) the effect of the perception of the impact of tourism on the attitude overall is reduced after controlling for life satisfaction $(\beta=.66$; $\mathrm{R}^{2}=.63 ;, p<.001$; indirect effect=.62; $p<.001$ ). The test bootstrap (Hayes, and Preacher, 2014; Hayes, 2009; Hayes, \& Preacher, 2014) carried out in 2000 bootstrap samples, with a confidence interval of 95\% Monte Carlo parametric bootstrap, indicating that there is a partial mediation (Lower limit $=.243$; Upper limit $=.061 ; z=.050, p<.001$ ), also, the results of the Sobel test (Sobel, 1982, 1986) indicate that the reduction of the regression coefficient is significant ( $p=.027$ ). The results suggest that there is average life satisfaction compensates in part for the relationship shown between TIAS and Attitude Toward Global by the residents of Taormina.

Table 3. HLM models of mediation using a 3-step procedure derived from Baron and Kenny (1986); SWLS as mediator of Attitude Toward Global and TIAS (* $\left.p<.001 ;{ }^{*} p<.05\right)$ )

\begin{tabular}{lcc}
\hline Variable & Dependent & Mediator \\
\hline Step1 & $\beta$ & $\beta$ \\
TIAS - Attitude Toward Global & $.50^{*}$ & \\
$\mathrm{R}^{2}=.25$ & & \\
Step2 & & \\
TIAS - SWLS & $.24^{*}$ & \\
$\mathrm{R}^{2}=.06$ & & \\
Step3 & & \\
TIAS - SWLS - Attitude Toward Global & $.66^{\star \star}$ & $.62^{\star}$ \\
$\mathrm{R}^{2}=.63$ & & \\
\hline
\end{tabular}

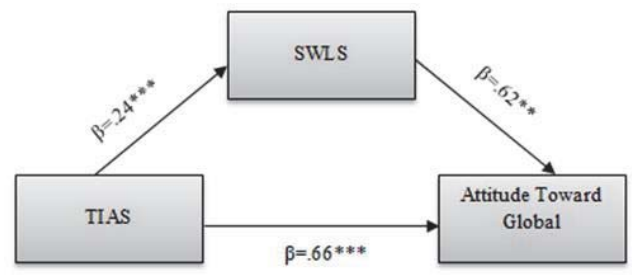

Figure 1. Summary of the support found for the research hypotheses (the values are the mixed-models regression estimates (Note: ${ }^{*} p<0.05$ and ${ }^{* \star} p<0.001$ ).

\section{Discussion}

The overall objective of the study was to verify the attitude of the residents of Taormina regarding the tourism phenomenon in the light of a series of psychological and socio-economic variables. Specifically, in addition to showing the influence of the independent variables mentioned, the goal was to identify the attitudes expressed by residents 
towards tourism, the perception of the impact of tourism on the resident, and if the relationship between the two constructs is can be mediated in the resident's expressed sense of life satisfaction.

As regards the influence of the socio-economic independent variables, residents with higher income are indicated as showing a more favorable attitude in reaction to the impact of tourism, rendering this a confirmation of the results obtained in literature (Lankford \& Howard, 1994). The economic level also affects the satisfaction experienced in one's own life, along with the level of employment and academic titles. This means that with perceived higher income, greater academic accomplishment and professional autonomy, there is a consequent increment in life satisfaction (Santisi, Platania \& Paolillo, 2013; Platania, 2010; Platania \& Santisi, 2015).

With respect to attitudes regarding the tourist figure and the values inherent in life satisfaction, for the first time in literature it is the latter that is considered as a possible precursor, and not simply a consequence of the impact of tourism on the quality of life of residents: in fact, the results highlight the importance that the resident contributes to the touristic and economic development of the community (in this case, of course, Taormina), historically considered as a tourist destination of excellence. Besides this, it is clear that citizen involvement is needed in the planning of services, especially because of the concrete impact that tourist development creates (Gursoy, Chi \& Dyer, 2010).

It is therefore necessary, first of all, to preserve from criteria of environmental, economic and social concerns, the community's cohesion and its inhabitants quality of life; also taking into consideration that in most cases only the residing local citizenry can understand the real value that tourism can assume in their community (Harrill, 2004; Pilato, Platania \& Rizzo, 2015). On the other hand, it is equally important to intervene on perceptions of this phenomenon and the attributions of values implicit in this attitude. Regarding the relationship between the over-all attitude towards tourism and TIAS, we can see that there is a positive, correlative relationship, which makes one presume that the antecedent, subjective attitude expressed by residents (that is, certain beliefs regarding the phenomenon, affecting the perception of the impact of tourism in resident and tourist-resident relations as defined in this paper), can positively confirm previous studies, (Teye, Sönmez \& Sirakaya, 2002; Gursoy \& Rutherford, 2004). Finally, as mediator for the effect of life satisfaction, this element affects tourists residing in the community, therefore casting an influence determined by conceptions related more to one's own personal development and cultural identity rather than a solely objective assessment of the tourist phenomenon, as already shown by related research (Nawijin \& Mitas, 2012).

In other words, the results of this study make it clear that support of tourist development as part of local community involvement is also developed taking into consideration the impact that may involve psychological determinants, and this factor can also affect attitudes, a sense of community acceptance, and its quality of hospitality.

This document is restricted in some aspects. Only residents were included in this study, but it can be interesting to study the perception of tourism impact of tourists residents. Study has only detected the tourism impact perception by residents, but does not analyze the relationship between tourist and resident. In addition, the repute the research is only a case study, it is difficult to generalize findings to other settings. Research should also focus on monitoring perceptions and attitudes of residents above Taormina time, in order to better identify how changes in the flow of tourism, the development policies and social economic situation in general affects residents perceptions and attitudes toward tourism.

Research provides the basis for a reflection on possible future actions concerning the promotion and sensitization of the territory and therefore may be a step toward increased at understanding of the industry and, ultimately, greater support of the benefits to a community. This is all the more important where the context of economic and politicalinstitutional references (in our case, Sicily) should be characterized as a driving force to obtain results rather than only an obstacle to overcome in promoting tourism.

(Platania, Ramaci \& Santisi, 2011).

\section{References}

Allen L.R., Long P.T., Perdue L.L., Kieselbach S. (1988). The impacts of tourism development on resident's perception of community life, Journal of Travel Research, 27, 16-21.

Almeida-Santos, C., Buzinde, C. (2007). Politics of identity and space. Representational dynamics. Journal of Travel Research, 45 (3), 322-332.

Andereck K.L., Nyaupane G.P. (2011). Exploring the Nature of Tourism and Quality of Life Perceptions among Residents. Journal of Travel Research, 50 (3), 248-260.

Andriotis, K., Vaughan, R. (2003). Urban residents' attitudes toward tourism development: The case of Creta. Journal of Travel Research, 42 (2), 172-185.

Ap, J., Crompton, J. L. (1993). Residents' Strategies for Responding to 1991. Tourism Impacts. Journal of Travel Research, 23, 47-50.

Apostolopoulos Y., Leontidou L., Loukissas P. (2014). Mediterranean Tourism: Facets of Socioeconomic Development and Cultural Change. London: Routledge. 
Arbuckle, J. L., Wothke, W. (1999). AMOS 4.0 user's guide. Chicago (IL): Small Waters.

Bachleitner R., Zins A.H. (1999). Cultural Tourism in Rural Communities: The Residents' Perspective, Journal of Business Research, 44 (3), 199-209.

Baron, R.M., Kenny, D.A., (1986). The moderator-mediator variable distinction in social psychological research: Conceptual, strategic, and statistical considerations. Journal of Personality and Social Psychology 51 (6), 1173-1182.

Butler, R. W. (1975). Tourism as an Agent of Social Change, in Proceedings of the International Geographical Union's Working Group on Geography of Tourism and Recreation, September 1974, Dept. of Geography, ed., Trent University, Peterborough, Ontario, pp. 85-90.

Butler, R. W. (1980). The Concept of a Tourist Area Cycle of Evolution: Implications for Management of Resources. Canadian Geographer, 24 (1), 5-12.

Brunt. P., Courtney P. (1999). Host Perceptions of Sociocultural Impacts, Annals of Tourism Research, 26, 493-515.

Canan, P, Hennessy M. (1989). The growth machine, tourism, and the selling of culture. Sociological Perspectives, 32, (2), $227-43$.

Carmichael, B. A. (2006). Linking Quality Tourism Experiences, Residents' Quality of Life, and Quality Experiences for Tourists, in Jennings, G., Nickerson, N.P, Quality Tourism Experiences, Burlington, MA: Elsevier Butterworth-Heinemann.

Diener, E. (1984). Subjective well-being. Psycho logical Bulletin, 95, 542-575.

Diener, E., Emmons, R. A., Larsen, R. J. \& Griffin, S. (1985). The Satisfaction With Life Scale. Journal of Personality Assessment, 49, 71-75.

Dogan, H. (1989). Forms of Adjustment: Socio-Cultural Impacts of Tourism. Annals of Tourism Research, 16 (2), $216-236$.

Doxey, G. V. (1975). A Causation Theory of Visitor-Resident Irritants: Methodology and Research Inferences, in Proceedings of the 6th Annual Conference of the Travel Research Association, Travel Research Association ed., Travel Research Association, San Diego, CA., 195-198.

Draper, J. K., Woosnam M., \& Norman, W. C. (2011). Tourism Use History: Exploring a New Framework for Understanding Residents' Attitudes toward Tourism. Journal of Travel Research, 50 (1), 64-77.

Filep, S., Deery, M. (2010). Towards a Picture of Tourists' Happiness. Tourism Analysis, 15 (4), 399-410.

Getz, D. (1986). Models in Tourism Planning. Tourism Management, 7 (1), 21-32.

Getz, D. (1994). Residents' attitudes towards tourism: A longitudinal study of Spey Valley, Scotland. Tourism Management, 15, (4), 24758.

Gursoy, D., Chi C., Dyer P. (2010). Locals' Attitudes toward Mass and Alternative Tourism: The Case of Sunshine Coast, Australia. Journal of Travel Research, 49 (3), 381-94.

Gursoy, D., Rutherford, D.G. (2004). Host attitudes toward tourism: An Improved Structural Model, Annals of Tourism Research, 31 (3), 495-516

Harrill, R., Potts, T. D. (2003). Tourism planning in historic districts: Attitudes toward tourism development in Charleston. Journal of the American Planning Association, 69 (3), 233-44.

Harrill, R. (2004). Residents' Attitudes toward Tourism Development: A Literature Review with Implications for Tourism Planning, Journal of Planning Literature, 18 (3), 251-66.

Huh, C., Vogt, C. (2008). Changes in Residents' Attitudes toward Tourism over Time: A Cohort Analytical Approach. Journal of Travel Research, 46 (4), 446-55.

Ishikawa, N., Fukushibe, M. (2006). Who expects the municipalities to take initiative in tourism development? Residents' attitudes of Amami Oshima Island in Japan. Tourism Management, 28, 461-475.

Jurowski, C. (1998). A study of community sentiments in relation to attitudes toward tourism development. Tourism Analysis, 3, 17-34.

Lankford, S. V., Howard, D. R. (1994). Developing a Tourism Impact Attitude Scale. Annals of Tourism Research, 21 (1), $121-139$.

Lindberg, K., Johnson, R. L. (1997). Modeling resident attitudes toward tourism. Annals of Tourism Research, 24(2), 402-424

Lepp, A. (2007). Residents' attitudes towards tourism in Bigodi village, Uganda. Tourism Management, 28, 876-885.

Maeran, R. (2004), Psicologia e turismo, [Psychology and Tourism ] Roma-Bari: Laterza.

Martin, B., McGuire, F. \& Lawrence, A. (1998). Retirees' attitudes toward tourism: Implications for sustainable development. Tourism Analysis, 3 (1), 43-51.

McCool, S. F., Steven R. M. (1994). Community attachment and attitudes toward tourism development. Journal of Travel Research, 32 (2), 29-34.

McGehee, N. G., Andereck K., L. \& Vogt, C. (2002). An examination of factors influencing resident attitudes toward tourism in twelve Arizona communities. http://www.ttra.com (accessed August 22, 2003).

McGehee, N., Andereck, K. (2004). Factors predicting rural residents' support of tourism. Journal of Travel Research, 43 (2), 131-140.

McNaughton, D. (2006). The 'Host' as Uninvited 'Guest': Hospitality, Violence and Tourism. Annals of Tourism Research, 33 (3), $645-$ 665.

Nawijn, J., Mitas. (2012). Resident Attitudes to Tourism and Their Effect on Subjective Well-Being: The Case of Palma De Mallorca, Journal of Travel Research, 51 (5), 531-41.

Nepal, S. (2008). Residents' Attitudes to Tourism in Central British Columbia, Canada. Tourism Geographies, 10 (1), $42-65$.

Oktay D.(2006). How can urban identity and Sustainability? Evaluations on Taormina (Sicily) and Kirenya (north Cyprus), Web Journal on cultural patrimony- webjournal.it 07/2006; 1 (2).

Osgood, C., Suci, G. \& Tannenbaum, P. (1957). The Measurement of Meaning. Urbana (IL): University of Illinois Press.

Perdue, R. R., Long, P., T., Allen, L. (1990). Resident support for tourism development. Annals of Tourism Research, 17, (4), 58699. 
Pizam, A. (1978). Tourism's impacts: The social costs of the destination community as perceived by its residents. Journal of Travel Research, 16 (4), 8-12.

Platania, M. (2014). Trade advantage of Italian industrial districts: Persistence and change Regional and Sectoral Economic Studies, 14 (2), 39-52. http://www.scopus.com/inward/record.url?eid=2-s2.084918577455\&partnerlD=40\&md5=5276e889039e8b4b57ec82e f3df8eb1

Pilato, M., Platania, M., Rizzo, M. (2015). The value of country of origin in the consumption. Results of a survey on Sicilian products Quality - Access to Success, 16, 150-157.http://www.scopus.com/inward/record.url?eid=2-s2.084939460999\&partnerlD=40\& md5=9fe68a1595a31fe3a62b145a84c2eee3

Platania, M., \& Privitera, D. (2006). Typical products and consumer preferences: The "soppressata" case. British Food Journal, 108(5), 385-395.

Platania S., (2013). Marketing territoriale e valorizzazione del prodotto tipico locale: una ricerca nel contesto siciliano [Territorial marketing and enhancement of the local product: a search in the context Sicilian]. In: Annali della facoltà di Scienze della formazione, Università degli studi di Catania, 12 (2013), 133-145, ISSN 2038-1328 / EISSN 2039-4934, 7 http://dx.doi.org/10. 4420/unict-asdf.12.2013.8

Platania S., Santisi G., (2015). Use of Alternative and Complementary Medicine by Old Italians Adults: The Determinant of Choice. In Open Journal of Social Sciences, 3, 293-299. http://dx.doi.org/10.4236/jss.2015.37042.

Platania S., Ramaci T., Santisi G. (2011). La motivazione alla scelta turistica in Sicilia: un confronto tra la percezione del turista e quella del portatore di interesse locale [The motivation tourist choice in Sicily: a comparison between the perception of the tourist and that of the bearer of local interest]. In TURISMO E PSICOLOGIA, 1, ISSN: 2240-0443- Padova University Press

Platania S., Santisi G., (2014). Luxury tourism e processi cognitivi di scelta della struttura turistica: un contributo di ricerca nel territorio siciliano [Luxury tourism and cognitive processes of choice of the tourist: a contribution to research in Sicily]. In Psicologia e Turismo, 1, pp. 1-11, ISSN: 2240-0443- Padova University Press, http://dx.doi.org/10.14658/tp-2014-1.

Platania, S., (2010). Comportamenti di consumo e costruzione di nuove identità: la valenza cognitiva del brand equity [Consumer behavior and the construction of new identities: the cognitive value of brand equity], in Annali Facoltà di scienze della Formazione, Università degli Studi di Catania, 7 (2008), 191-221. ISSN 2038-1328 / EISSN 2039-4934 http://dx.doi.org/10.4420/ unict-asdf.7.2008.10

Roccuzzo T.(2001).Taormina l'isola del cielo. Come Taormina divenne Taormina [Taormina the island in the sky. Taormina became Taormina]. Catania: Maimone.

Ryan, C., Cave, J. (2005). Structuring destination image: A qualitative approach. Journal of Travel Research, 44 (2), $143-150$.

Rasoolimanesh S.M., Jaafar M., Kock, N. Ramayah T.(2015). A revised framework of social exchange theory to investigate the factors influencing residents' perceptions, Tourism Management Perspectives, 16, 345-355.

Santisi G., Platania S. (2014). II rapporto tra il consumatore e il mass marketing brand: la determinante di scelta del centro commerciale [The relationship between the consumer and the mass marketing brand: the determinant of choice of shopping center]. In Micro \& Macro Marketing, XXIII, 3, 461-476. http://dx.doi.org/10.1431/78568, ISBN 978-88-15-24961-6.

Santisi G., Platania S., Hichy Z. (2014). A lifestyle analysis of young consumers: a study in Italian context. In YOUNG CONSUMERS INSIGHT AND IDEAS FOR RESPONSIBLE MARKETERS 15(1), 94-104, http://dx.doi.org/10.1431/78568.

Santisi G., Alario M. (2014). L'innovazione nell'impresa artigiana. L'apprendimento organizzativo tra pratiche generative e intersoggettività [The artisan in the enterprise innovation. Organizational learning between generative and intersubjectivity practices], in «Quaderni di ricerche sull'artigianato», 3, 341-362. ISSN 1590-296X. Doi: 10.12830/78773.

Santisi G, Platania S., Paolillo A. (2013). Sviluppo del territorio e politiche del turismo: la valutazione dellimpatto turistico dal punto di vista dei residenti. [Land development and tourism policies: the assessment of the tourism from the point of view of the residents]. In Turismo e Psicologia, v01, 106-117, ISSN: 2240-0443- Padova University Press.

Schalock, R. L. (1996). Quality of Life: Conceptualization and Measurement, 1, Washington, DC: American Association on Mental Retardation.

Sirakaya-Turk, E., Ekinci, Y. \& Kaya A. (2008). An Examination of the Validity of SUS-TAS in Cross-Cultures. Journal of Travel Research, 46 (4), 414-21.

Sobel, M. E. (1982). Asymptotic Confidence Intervals for Indirect Effects in Structural Equation Models. Sociological Methodology, 13, 290-312.

Sobel, M. E. (1986). Some New Results on Indirect Effects and Their Standard Errors in Covariance Structure. Sociological Methodology, 16, 159-186.

Teye, V., Sönmez, S. \& Sirakaya, E. (2002). Resident Attitudes toward Tourism Development. Annals of Tourism Research, 29 (3), 668688.

Um S., Crompton J.L., 1987, Measuring resident's attachment levels in a host community. Journal of Travel Research, 26, 27-29.

Veenhoven, R. (2009). How Do We Assess How Happy We Are? Tenets, Implications and Tenability of Three Theories, in Dutt, A.K., Radcliff, B., Happiness, Economics and Politics: Towards a Multidisciplinary Approach, Cheltenham, UK: Edward Elger, 45-69.

Vesey, C, M., Dimanche F. (2000). Urban residents' perceptions of tourism and its impacts, Unpublished manuscript, University of New Orleans, LA.

Wall, G., Mathieson, A. (2006). Tourism: Change, Impacts and Opportunities. Harlow, UK: Pearson.

Wang, Y., Pfister, R. E. (2008). Residents' Attitudes toward Tourism and Perceived Personal Benefits in a Rural Community. Journal of Travel Research, 47 (1), 84-93. 
Williams, D. R., McDonald C. D., Riden C. M. \& Uysal M. (1995). Community attachment, regional identity and resident attitudes toward tourism development. 26th annual conference proceedings of the Travel and Tourism Research Association. Acapulco, Mexico: Travel and Tourism Research Association, 424-431.

Woosnam, K. M., Norman, W. C. (2010). Measuring Residents' Emotional Solidarity with Tourists: Scale Development of Durkheim's Theoretical Constructs. Journal of Travel Research, 49 (3), 365-80.

Zhang, J., Inbakaran, R., \& Jackson, M. (2006). Understanding community attitudes towards tourism and host-guest interaction in the urban-rural border region. Tourism Geographies, 88 (2), 182-204. 